\title{
Computers in Physical Therapy Education: Interactive Multimedia Learning with MuStreT
}

\author{
Luciana Vieira CASTILHO-WEINERT, Heitor Silvério LOPES \\ Medical Informatics and Bioinformatics Laboratory, Federal University of Technology Paraná \\ Av. 7 de setembro, 3165 - Curitiba (PR), Brazil \\ e-mail: lucianaweinert@gmail.com; hslopes@pesquisador.cnpq.br
}

Received: June 2009

\begin{abstract}
Muscular strength tests are of fundamental importance for the physiotherapeutic diagnosis and a difficult issue for learning. Also, there are very few softwares specifically developed for teaching/learning and diagnosis in the Physical Therapy area. This work describes the development and evaluation of MuStreT, an educational multimedia computer tool for Physical Therapy students. MuStreT integrates hypertext, movie clips, narrations, animations, self-evaluation questionnaires, and was inspired by the constructivism concepts. The software was developed using Unified Modeling Language concepts and implemented using animation and authoring tools. MuStreT was quantitatively evaluated by Physical Therapy students and qualitatively evaluated by Physical Therapy professionals/lecturers and Computer Science students. Results show that learning was increased using MuStreT, thanks to its interactivity potential and multimedia features. This work suggests that the use of informatics in Physical Therapy education has a great potential for improving the teaching-learning process.
\end{abstract}

Keywords: multimedia system, interactive learning environment, media in education, simulations.

\section{Introduction}

The main objective of Physiotherapy is to promote and recover the functionality of an individual. The role of the physical therapist is to evaluate movement dysfunctions and apply adequate procedures to allow patient to recover his functions, aiming at reaching as close as possible the physiological normality. In this context, the evaluation of the patient is of fundamental importance to provide an accurate kinetic-functional (physiotherapeutic) diagnosis.

The first step of the physiotherapeutic diagnosis is the interview with the patient. After a detailed visual inspection of the patient, the physical examination is done, when the muscular strength tests are applied (Cipriano et al., 1999). Based on the information collected and the expertise of the physical therapist, the diagnosis is established.

The importance of the muscular strength tests is focused in detecting the traction power of the muscles. In the healthy individual, muscles contain the articular structures that provide the crank conditions to achieve movement and function. However, some clinical conditions may lead individual to have limited movement and loose function. 
Only with a precise diagnosis the physical therapist will be able to perform procedures to reestablish function.

According to undergraduate students and teachers of this area, there is a clear difficulty in managing muscular strength tests during the academic years. This fact was also observed by Jan et al. (2003), who pointed that Physical Therapy students consider hard to learn the dynamic aspects of Kinesiology.

In the Kinesiology textbooks, students can find only static images (most are not color). This makes difficult to understand the dynamics of the movement represented. Besides, the amount of information that is supposed to be acquired by the student is very large, taking into account the number of muscles of the human body and the corresponding muscular strength tests. According to the literature, there are 107 different tests (Hislop and Montgomery, 2007; Kendall et al., 2005; Clarkson, 2000; Cutter and Kevorkian, 1999) that should be recalled in the daily activity of the physiotherapist.

On the other hand, Kendall et al. (2005) point that the muscular strength test must be applied with special attention to details, since the lack of accuracy may lead to wrong diagnoses, and negative consequences to the treatment.

Motivated by the two previously mentioned issues: the difficulties faced by Physical Therapy students and lack of expressiveness of textbooks, this work reports the use of informatics in Physical Therapy education, presenting a multimedia learning system, named MuStreT (acronym of Muscular Strength Tests).

The objective of MuStreT is to provide complementary study material for undergraduate students after attending Kinesiology classes. This computational system allows the student to observe the execution of each test at home. Therefore, MuStreT aggregates more reality to the learning process, by means of the visualization of movements and animated explanations that cannot be represented in books.

Another important motivation for this work is the fact that, despite the great advancement in Computer Science and Physical Therapy, there are very few computational systems especially dedicated to support activities of the physiotherapists and, in particular, to their education.

\section{Health Informatics and Education}

Health informatics is the application of computers and information technology to the development of computational systems to the health sciences, as well as for the academic and professional education (Shortliffe et al., 2001). Although informatics is widely used for supporting most of the services in the several professional areas of health (Fieschi, 2002), it is a matter of fact that the majority of computational applications is directly related in Medicine. Much more sparsely found, there are also some applications in Nursery, Odontology, Nutrition and others.

Papers of computer applications in Physical Therapy are indeed rare, but always with promising results. For instance, McGouwn and Faust (1971) describe a pilot program for educational purposes in Physical Therapy, concerning a software for reviewing subjects 
of anatomy and physiology. Authors report very good results in the learning performance of students using this software. Also, Washington and Parniampour (1997) developed a tutorial system for learning biomechanics, achieving significant results. Saarinen-Rahika and Binkley (1998) proposed a tutorial system using Problem-Based Learning (PBL). In this study, the comparison of performance between students who used the software and those who did not showed significant difference in favor of the former group. Recently, Wilkinson (2007) developed a computer-based ontology for teaching specific issues of anatomy to Physical Therapy students. In this work, an improved performance of students who used the software was also verified.

In the teaching-learning theories aim at understanding how these processes occur. It is known that, for achieving efficiency, learning should occur simultaneously to teaching. For Jonassen (1992), the sociointeactionist theory (constructivist paradigm) is the model that most favor the teaching-learning process. According to this theory, by practicing the reality, students can transform information into knowledge and, consequently, learn. In this context, informatics is an efficient resource for providing realistic simulations, thus establishing a new paradigm for education.

In the constructivist paradigm, the student is considered individually and becomes the focus of the learning process. However, the student is also considered collectively, capable of influencing and being influenced by actions and thoughts emergent from constructive cooperation with other students. In this context, the student is the protagonist; the teacher is the advisor; and the computer is the mediator of the learning process.

Although, there is no definitive evaluation about the impact of the use of informatics in education, it is well known that its use in education is appealing and can make easier the learning complex subjects (Apperson et al., 2006; Hwang et al., 2006).

\subsection{Interactivity and Multimedia in Health Education}

The use of informatics in education presumes interactivity so as to achieve efficient learning. Interactivity means that learning should include the interaction between the learner and the object under study (Schrum and Berge, 1997). Informatics can provide multimedia resources which allow two ways of interaction: either started by the learner or by the computer program (Schär and Krueger, 2000).

Laurillard (2002) reports a three-step model for describing the interactivity started by computer-based multimedia systems: initiation, response and feedback. Using this model, Evans and Sabry (2002) describe an interactive system by means of a simple example: present button or control to learner (computer initiation), student presses button or control (learner response), present new information to learner (computer feedback).

Evans and Gibbons (2006) point out that interactivity in computer-based learning systems is only really is effective when started by the computer as an intrinsic part of the learning. Several principles have been formulated for the design of multimedia-based learning systems aiming at facilitating learning and improve interactivity. These are the five fundamental principles proposed by Mayer (2001): including the use of both words and pictures, avoiding different media, using narration rather than text, placing words and pictures close together and presenting words and pictures at the same time. 
Amongst the several different types of educational softwares, multimedia is, possibly, the one that most stands out, due to its features: the ease of simulation of sceneries, possibility of giving immediate feedback to the learner, and visualization of illustrations and animations (Mayer, 2001). In the academic environment, it is known that multimedia promotes increase of the attention level of the learner and it is preferred among the new learning technologies (Apperson et al., 2006; Hwang et al., 2006). In the computational systems for education in the health sciences, multimedia is a very important aid. Besides the already mentioned features, it is of particular importance the non-linearity and high level of reality in graphics and images. By means of multimedia subjects of difficult representation in textbooks can be easily presented with convincing realism. It can be cited, for instance, dynamic physiological phenomena, biochemical molecular reactions and kinetic behavior of muscles. The latter is the subject of MuStreT, presented in this paper.

\subsection{Muscular Strength Tests}

The muscular strength tests determine the ability of the muscles to perform movements. Kendall et al. (2005) and Clarkson (2000) point out that these tests are part of the procedures required for fully evaluating function and power of individual muscles or muscular groups.

Function or movement takes place by means of cranks, composed by the bones and articulations. In order to work properly, the integrity of muscles is fundamental. Muscular integrity is represented by the tensile force (Smith, Weiss and Lehmkuhl, 1996) that is evaluated by means of the muscular strength tests. Besides, Clarkson (2000) asserts that the correct execution of the tests is essential to evaluate further progress and efficiency of the physiotherapeutic treatment.

In undergraduate Physical Therapy courses, such tests are part of the syllabus of kinesiology, usually taught in the first or second year of the course, so as to foster the diagnostic abilities of the students.

Fig. 1 represents a typical illustration found in a textbook of kinesiology, for the ulnar flexor muscle of wrist and its elements. Together with the picture, the student will find a description of the elements of the test, as follows:

- Patient: sat or in dorsal decubitus.

- Test: wrist flexion towards ulnar side.

- Setting: the physiotherapist supports the forearm.

- Pressure: against hypothenar eminence towards extension.

The simple observation of the figure and its text description are quite far from the dynamic reality of the movement. Besides, this description necessarily includes abundant terminology about anatomy that the student must know.

This example illustrates how difficult is the comprehension of the several muscular strength tests by the undergraduate student who can count only with the aid of textbooks subject to complex interpretation. 


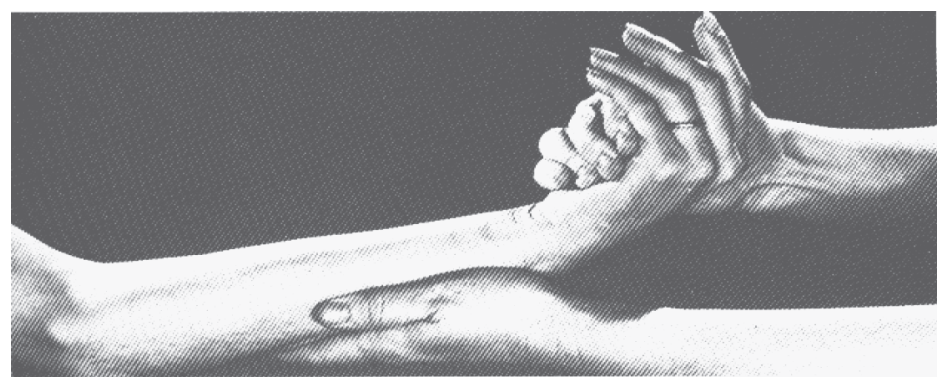

Fig. 1. Ulnar flexor muscle of wrist test. Adapted from Kendall et al., (2005).

\section{The MuStreT Software}

MuStreT was aimed at being a tool for the student, not for the teacher, to support his learning of the muscular strength tests. Since it is focused on the student, the system was developed under the pedagogical theory of constructivism. The constructivist approach presupposes active and individualized learning, in which knowledge is acquired by the interaction of the student with a rich environment as close as possible to the reality.

MuStreT is an educational multimedia software and has multiple resources for stimulating the learner, such as video clips, animations, audio narratives, and texts. Therefore, the proposed system encompasses several teaching methods: visual, oral and written, providing adaptability to the user profile. During the development of MuStreT, it was a continuous concern to explore the potential opportunities of interactiveness in the interface with the learner.

A computational system aimed at being an educational tool must include, besides pedagogical techniques, knowledge about the domain it is applied to. The source of knowledge used in this work was textbooks of kinesiology. The books that provided theoretical reference for this work were those currently used in most Brazilian universities for undergraduate courses of Physical Therapy, more specifically: Hislop and Montgomery (2007), Kendall et al. (2005), Clarkson (2000), Cutter and Kevorkian (1999).

\subsection{Modeling of the System}

The development of a logical model before to implement the physical model leads to a software of better quality and usually shortens the development cycle. MuStreT was developed based on the principles of the Unified Modeling Language (UML) (Larman, 2004).

According to the UML, one of the first steps of a software project is the construction of a Use Case Diagram (UCD). This behavioral diagram presents graphically all the functionalities the proposed system will offer to the user, defining the navigation paths available to the user and the interaction of this with the system. In other words, the UCD surveys the requirements to be satisfied by the program (Larman, 2004). Fig. 2 presents the UCD of MuStreT, showing the interaction of the system with the student and vice- 


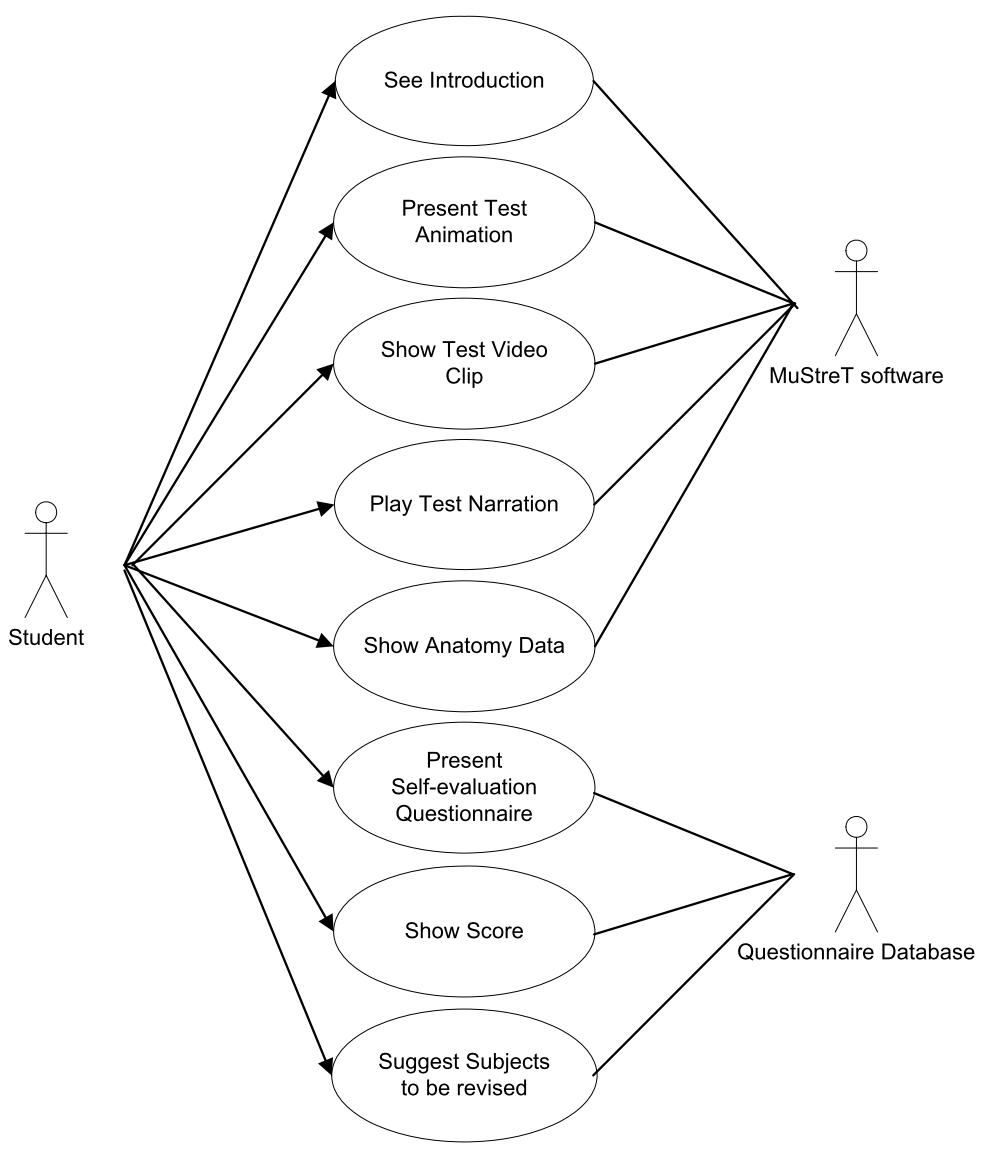

Fig. 2. Use-case diagram to achieve the requirements survey.

versa. The ellipses represent the interactive services of the system. Such interactivity is always started by the computer, as recommended by Evans and Gibbons (2006).

\subsection{Animation Procedure of the Muscular Strength Tests}

In this work we used Adobe Flash ${ }^{1}$ for creating vector graphs and interactive animations. This software can also be used for implementing navigation interfaces and high-quality graphical effects. Graphs generated by Flash are more compact than regular bitmap files and do not loose resolution when enlarged (Lentz e Dowd, 2003).

The creation and manipulation of images to be animated takes place in the stage part of the software. Considering that a movie is the successive visualization of frames, in the timeline of Flash it is possible to set in which frame the animation should start and finish, thus establishing its duration. The possibility of inserting figures in different layers of

\footnotetext{
${ }^{1}$ Available at: http://www.adobe.com/br/products/flash/.
} 


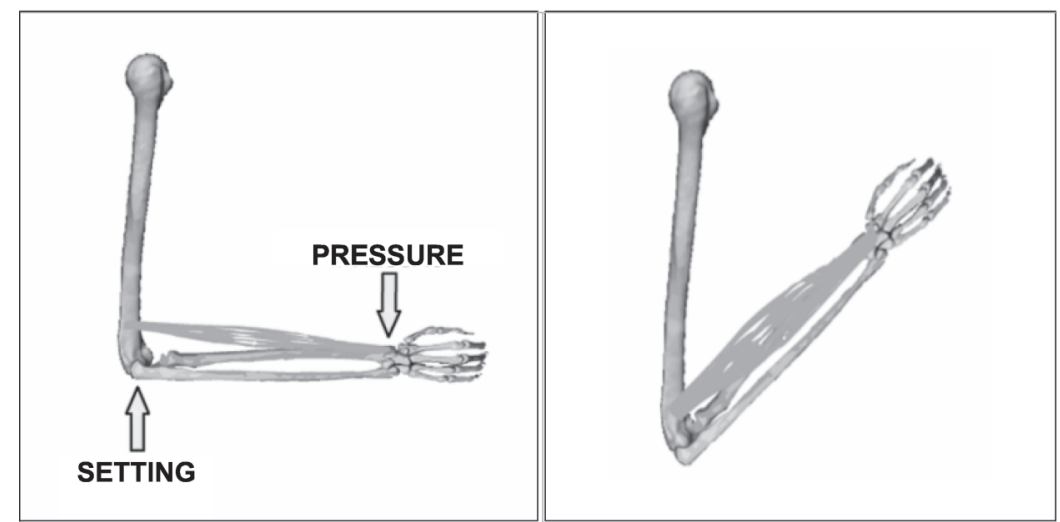

Fig. 3. Test movement of the brachioradialis muscle. (a) initial state of the animation (b) final state of the animation.

timeline allows several objects of the same frame to be independently animated. For example, in the animation of movements of a hand and fingers, each finger can be animated in a layer, and thus it is possible to construct differentiated movements for the fingers.

The development of the animations used in MuStreT is depicted in Fig. 3a and Fig. 3b, corresponding to the initial and final figures for the animation of the brachioradialis muscle. The animations simulate the dynamics of the test as close as possible to the reality. They also present the location of the muscle under test in the human skeleton and the correct positioning and movement of the hands of the physical therapist during the execution of the test. This richness of details contrasts with the poor information presented in textbooks as black-and-white static pictures.

All the tests were animated using Flash, and then used for composing the multimedia representation of MuStreT.

\subsection{Narrations and Videos}

In MuStreT, the video clips of the muscular strength tests are presented side by side to the animations. These videos aim at giving a spatial representation of each test using real people. Together with the execution of the video, the user hears the narration of the test using the appropriate technical jargon. The objective of video clips is to show an "external" representation of the test, while the animations show the "internal" representation. The advantage of using a video clip is to show exactly how a professional would execute the test, and the advantage of an animation is to illustrate how behaves the muscle under test.

Animations, video and narrations are always synchronized in MuStreT, thus giving to the student not only information, but also hearing and visual stimuli. This multimedia approach corroborate with Mayer (2001), who states that the learning of contents by the student is increased when audiovisual resources are associated in a stimulating environment. 


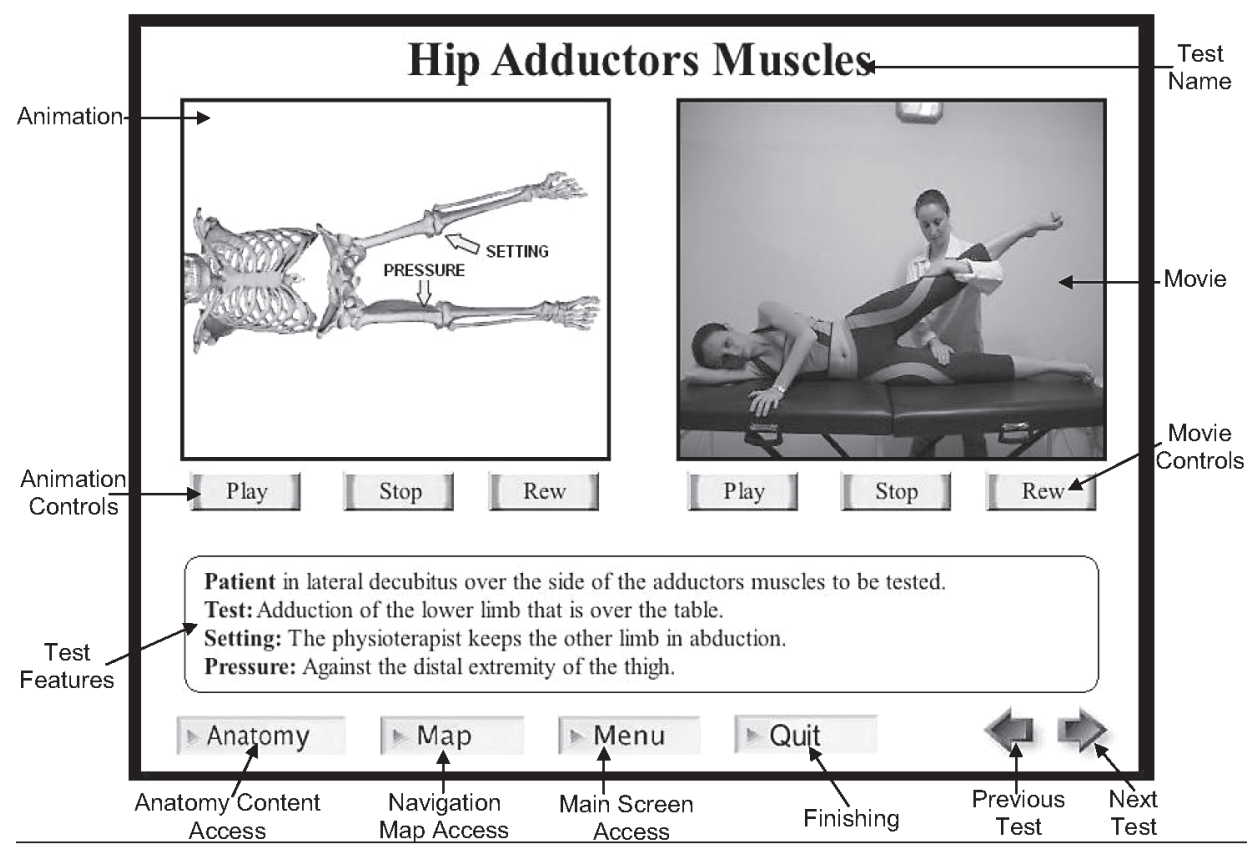

Fig. 4. Screen from a muscular strength test.

\subsection{Software Implementation}

The framework for implementing MuStreT was the authoring software Adobe Director ${ }^{2}$. It allows the creation of visual presentations enriched with interactive multimedia (audio and video clips). This software is based on a metaphor of a theatrical production. All the action takes place in the stage and the elements composing the cast are named "sprites". The sequence of multimedia screens is defined according to the timeline named "score". This timeline determines where and when the elements of the cast should be. The final production of Director is a executable file named film.

Fig. 4 shows a screen shot of MuStreT in which development the interactivity was emphasized in the user interface, thus following Evans and Gibbons (2006) who stated that interactivity is guaranteed provided it is started by the computer. Therefore, in all screens, the user is presented to buttons that lead the user to start intuitively the multimedia resources. Video clips or animations can be started separately or simultaneously. The narration of the variables of the test is synchronized with the corresponding video clip.

Fig. 5 shows the navigation map in which all the functionalities of the system are shown. This map can be accessed from any screen, allowing the non-linear navigation of the user. This feature of MuStreT was designed to fit the particular level of each student, and also facilitates the accessibility to those users with less affinity with informatics (such as the students of Physical Therapy).

\footnotetext{
${ }^{2}$ Available at: http://www. adobe.com/products/director/.
} 


\section{Navigation Map}

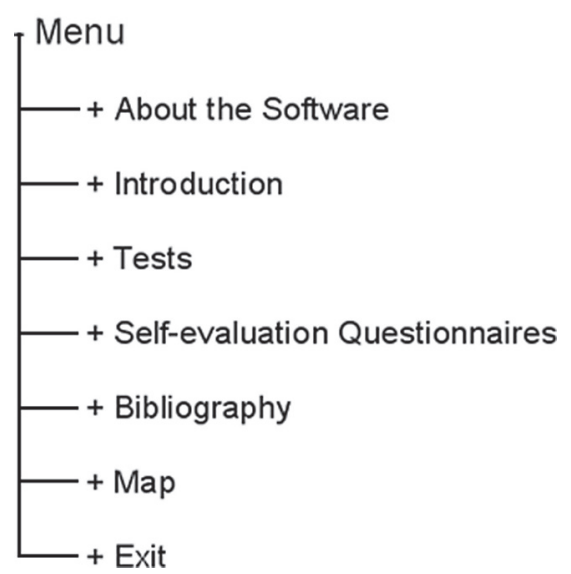

Fig. 5. Navigation map.

\subsection{Implementation of Self-Evaluation Questionnaires}

Besides the several multimedia-enriched screens in which the student can interact with the computer aiming at improve his/her learning, MuStreT also makes available selfevaluation questionnaires at the end of tests of a given body segment. The objective of these questionnaires is to quantify the knowledge of the student at a given level, regarding the muscular strength tests studied in the computer.

The interactivity of the self-evaluation questionnaires is of great relevance in this work, since the feedback provided to the student leads the software to be inserted in the context of the constructivist paradigm described by Jonassen (1992) and Laurillard (2002). This educational paradigm allows for an active, autonomous and user-centered learning. Learning is active because the student interacts with the system when he/she chooses an answer for the question presented. Learning is autonomous because it is independent of the presence of the teacher. Finally, learning is user-centered because it supplies a written report about the performance of the student.

The self-evaluation questionnaires were implemented using Borland C-Builder ${ }^{3}$, version 5.0. A large database of questions and answers about the several muscular strength tests was constructed by an expert physical therapist, based on the contents of the screens and on her professional experience. For each session to the self-evaluation questionnaires 10 randomly chosen questions are presented. After finishing answering the questionnaire, the student receives a printable report with the number of correct answers and a suggestion of the subjects that deserve to be reviewed (corresponding to the questions answered wrongly). This procedure reinforces interactivity with the system: besides the feedback of the number of correct answers, it points out what the student should continue studying in order to clear out his/her doubts. The dynamics of the self-evaluation questionnaires is shown in Fig. 6 in the form of a directed graph. 


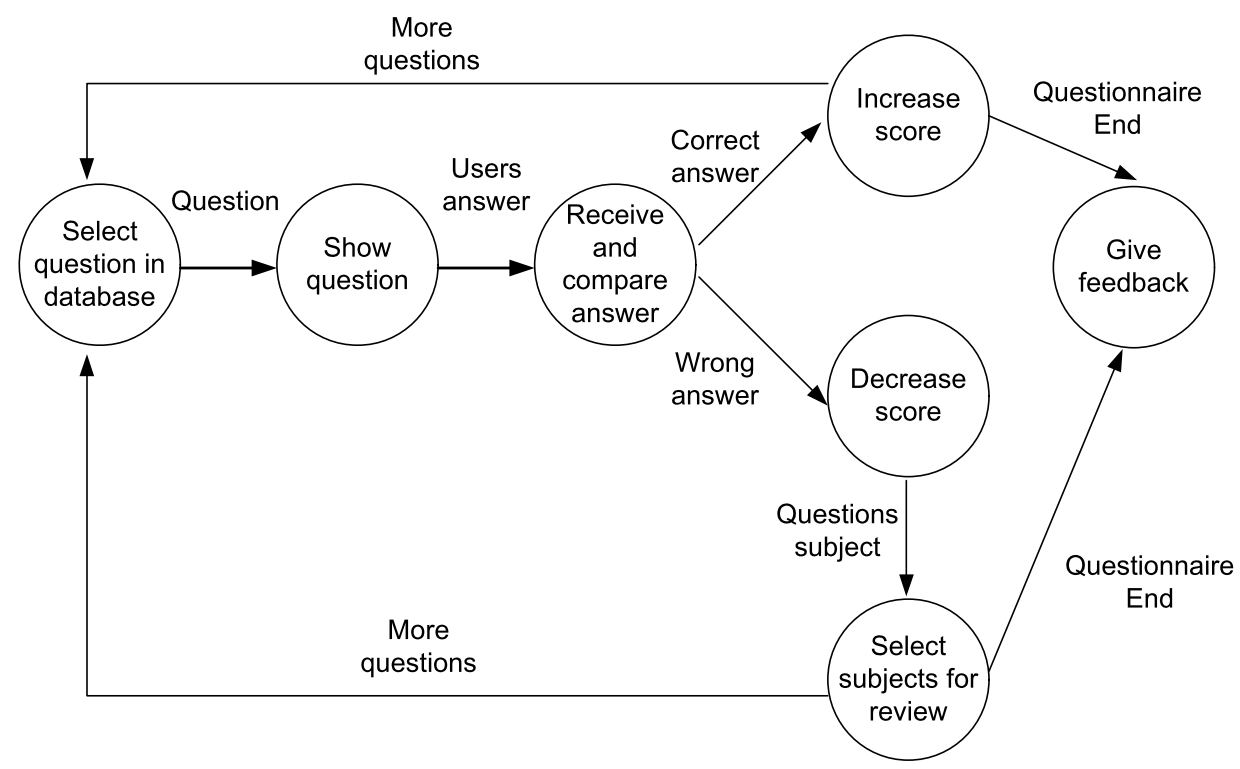

Fig. 6. Directed graph representing the navigation flow of the self-evaluation questionnaires.

\section{Evaluation and Results}

The evaluation of MuStreT was based on the proposal of Wilkinson (2007) for the analysis of learning technologies in Physical Therapy. This author calls the attention to the necessity of quantifying the performance differences between groups of subjects who had access to the technology and those who did not. It is also pointed out that the evaluation should address the user interface regarding its interactivity and usability. Therefore, both quantitative and qualitative evaluations were done, as follows.

The first evaluation quantified the learning of Physical Therapy students, regarding the subject of muscular strength tests, by comparing the performance of those who used and those who did not used MuStreT. Next, a qualitative evaluation was done focusing the necessity and demand for the multimedia learning system. This was done by means of interviews with specialized professionals. Finally, a further qualitative evaluation was done to address the user interface, and this was done interviewing Computer Science students.

The results from all these three evaluations are reported and discussed below.

\subsection{Quantitative Evaluation}

A quantitative evaluation was done with 40 second-year Physical Therapy students, comparing the learning of a group who used both MuStreT and textbooks, and a group who used only textbooks. The main objective of this evaluation was to access the efficiency of MuStreT in promoting learning gain about muscular strength tests. 
The students were divided into two groups, A and B. Group A studied muscular strength tests using textbooks and MuStreT software. The software was installed in 10 computers and made available to only these students for two weeks. The other group was the control, in which students had the same classes, but access only to textbooks. After two weeks in which the software was available to the students, both groups were submitted to a test for evaluating the learning in this specific subject. The test had 10 objective questions proposed by expert physical therapists.

It is important to notice that the quantitative evaluation was done with students of a private university, different from that of the developers of MuStreT, although in the same city (Curitiba, Brazil). Those students were encouraged to use the software by their teachers, who also were in charge of applying the quantitative evaluation test. Such teachers did have any relationship with the development of MuStreT. All these issues were carefully observed so as to guarantee the fidelity of the evaluation.

We verified that $43 \%$ of students in group A achieved a number of correct answers above $50 \%$, whereas only $29 \%$ of students in group B achieved such score. Therefore, it can be stated that the learning was more efficient when using MuStreT as an educational tool.

\subsection{Qualitative Evaluation by Physical Therapy Professionals}

A qualitative evaluation was done with 10 physical therapists who had 8 years of professional clinical practice, in average. Besides, all of them had academic experience as lecturers of Physical Therapy courses. The participants belonged to four different universities (all in Curitiba, Brazil), excluding the institution where MuStreT was developed. None of them participated of the development of the software.

The objective of the qualitative evaluation was not only to estimate the difficulty level of the subject, but also to access the interactivity potential and usability of the software, both from the point of view of a physical therapyst. The opinion of professionals is quite relevant since they are supposed to have a broad view of Physical Therapy and the importance of muscular strength tests in the context of clinical practice. Also, due to their academic experience, they were able to evaluate the adequacy of the software for Physical Therapy students. They also provided useful information about the difficulty of teaching this subject and the difficulty in learning this subject by students.

After a detailed demonstration of the software, each professional was required to answer a questionnaire. Questions addressed the following issues:

- When student, how difficult it was to learn the muscular strength tests.

- What is the level of interestingness of a novel learning method using a multimedia system that possibly allows a better learning to students.

- How user-friendly is the user interface of the software, considering that health professionals usually do not have great affinity with informatics.

- What is the effectiveness to the learning of the self-evaluation tests of MuStreT and its studying suggestions.

From the replies obtained from the professionals we verified that $80 \%$ of them asserted that achieved grades between 4 and 7 in learning by means of the traditional learn- 
ing methods (while they were undergraduated students). Only $20 \%$ of the professionals mentioned that their performance was above $70 \%$. Regarding the use of textbooks when students, $40 \%$ of the professionals reported that they were interesting, $20 \%$ reported a moderate level of interestingness, and $40 \%$ reported that they were not interesting.

By unanimity, professionals agreed that the muscular strength tests is a difficult subject for students. Notwithstanding, they consider the tests as essential for the professional activity. These findings support their assertion that MuStreT can facilitate the learning of this subject to Physical Therapy students

The user interface of MuStreT was considered adequate and simple to interact by $90 \%$ of the professionals. The remaining $10 \%$ considered the interface fair. This result can be regarded as good, because no one considered the interface too complex for students or not user-friendly.

All professionals considered efficient the interactivity with the student of the selfevaluation questionnaires, thus suggesting that the software is updated with the recent pedagogical tendencies that foster an active learning.

When comparing how the muscular strength tests were represented in MuStreT and in textbooks, $90 \%$ of the professionals reported that the software is more expressive than textbooks. Only $10 \%$ argued that both, software and textbooks, have the same representativeness.

\subsection{Qualitative Evaluation with Computer Science Students}

This qualitative evaluation was done with 20 computer science students of a state university (in Ponta Grossa, Brazil). In this case, the objective was to evaluate the design of the user interface and functionality of the software, from the point of view of software developers. The students selected for this evaluation were those enrolled in a Man-machine Interaction undergraduate course. Therefore, they had enough knowledge about usability, learnability, acessibility and interactivity, so as to evaluate the interface features of MuStreT. This evaluation was, obviously, from the point of view of who do not know anything about the subject of the software, that is, muscular strength tests.

Besides the evaluation, a short presentation was done to the students about the general characteristics of interactive educational softwares, according to Laurillard (2002). They were also told about the five main features reported by Mayer (2001) about the design of multimedia learning systems. After, each student was requested to answer a simple questionnaire approving or not each characteristic (shown in Tables 1 and 2) and justifying his/her opinion.

Table 1 shows how the Computer Science students evaluated the interactivity potential of the software. They checked if interactivity was started by the computer and there was feedback after the learner's actions. In Table 2 it is shown the evaluation of the software interface, regarding usability, acessibility and learnability.

MuStret was broadly approved by the Computer Science students as an interactive multimedia tool. The written evaluation took important contributions to the improvement of the software. Two important suggestions drawn from the questionnaires that will be 
Table 1

Results from qualitative evaluation of interactivity characteristics

\begin{tabular}{lc}
\hline $\begin{array}{l}\text { Presence of Interactivity Characteristics } \\
\text { described by Laurillard (2002) }\end{array}$ & Students Approval Percentage \\
\hline $\begin{array}{l}\text { Computer Initiation: presenting buttons } \\
\text { Learner Response: pressing the button }\end{array}$ & $100 \%$ \\
Computer Feedback: & $70 \%$ \\
starting animation and/ or video and/ or narration & \\
Computer Initiation: & $100 \%$ \\
presenting self-evaluation questionnaires & $100 \%$ \\
Learner Response: answering the questions & $100 \%$ \\
Computer Feedback: giving the number of correct & \\
answers and suggesting contents to be revised & \\
\hline
\end{tabular}

Table 2

Results from qualitative evaluation of multimedia design

Presence of characteristics to design multimedia Students Approval Percentage related by Mayer (2001)

\begin{tabular}{lc}
\hline Using both words and pictures & $90 \%$ \\
Avoiding extraneous media & $100 \%$ \\
Using narration rather than text & $100 \%$ \\
Placing words and pictures close together & $90 \%$ \\
Presenting words and pictures at the same time & $100 \%$ \\
\hline
\end{tabular}

implemented in future versions are: visualization of animations and video clips in different angles or sizes, and increase of interactivity inserting images in the self-evaluation questionnaires.

As stressed before, one of the focuses of the evaluation of MuStreT was regarding its potential of interactivity. Interactivity is essential to improve the teaching-learning process and, consequently it should be carefully evaluated.

\section{Conclusions}

The results of the quantitative evaluation were coherent with the expectancy. We believe that the higher performance of group A, regarding the control group, was strongly influenced by the use of MuStreT as an auxiliary tool in the learning process. It was also observed that Physical Therapy students were not so enthusiastic in testing the software (in comparison with the Computer Science students). This fact is due to the low affinity of health students with computers in general and, in the academic curriculum, the use of computers is not encouraged. It is also worth to mention that softwares specifically 
created for the area of Physical Therapy are rarely found. Therefore, it comes out that, in future evaluations, a previous motivational procedure should be conducted in order to increase the engagement of students.

The average results obtained in the quantitative evaluation were significantly low for both groups. This strongly suggests that the subject "muscular strength tests" is really difficult for the students. Even so, students who used MuStreT had a better performance than those who did not and, therefore, it is believed that alternative learning methods, such as the proposed system, is capable of promoting a positive impact in learning.

The qualitative evaluation by physical therapists was satisfactory. The answers collected in the questionnaires indicated that practically all participants believe that MuStreT can improve the learning of students in muscular strength tests. This outcome is motivating since all of the professionals have academic experience as lecturers and are acquainted with the difficulties that students face to learn that subject. Besides, no one of the professionals considered that the conventional textbooks can represent the muscular strength tests better than the software, thus suggesting that MuStreT could even overcome textbooks.

The qualitative evaluation with Computer Science students revealed that the diversity of audiovisual resources in MuStreT allows a satisfactory level of interactivity with the user, also facilitated by its simple and intuitive user interface. Therefore it is possible to infer that the careful project and implementation of the software addressed all the desirable features of educational multimedia software, as described in the literature. The suggestions given by the Computer Science students were very important to improve the interactivity of the system. All suggestions will be implemented in future versions, understanding that interactivity is essential to fit MuStreT as more as possible to the constructivist paradigm described by Jonassen (1992). According to this paradigm, students can transform information into knowledge by practicing the reality through the interactivity with a learning tool.

The overall design of the user interface of MuStreT, its navigation system, and other user services were developed aiming at meeting the recent pedagogical tendencies. The constructivist principle (from the sociointeractionist theory) states that knowledge is acquired by practicing the "real", by means of an active and autonomous learning, and centered in the student. According to the principle, it is encouraged the individualized progress of the student as well as his/her initiative to receive stimuli from the environment and exercise some action to it (Jonassen, 1992; Mayer, 2001; Laurillard, 2002).

The development of MuStreT was done keeping in mind that interactivity had to be promoted whenever possible, and started by the computer, as suggested by Evans and Gibbons (2006). The objective was to drive and keep the attention of the student at the first contact with the software because, according to Evans and Gibbons (2006) the effect of interactivity in increasing learning has important implications for the design of new computer based learning systems. Considering that most Physical Therapy students are not quite familiar with informatics, the system was projected to be easily used, once it started each interaction with the user.

The acceptance of the professionals/lecturers indicates that MuStreT is an inovative approach for the teaching-learning process in Physical Therapy education. Results sug- 
gest that it can facilitate students to acquire more efficiently knowledge about the muscular strength tests and, therefore, can help them to evolve their diagnostic abilities for their professional live.

The final conclusion that might be drawn, as mentioned by Apperson et al. (2006) is that, although the use of multimedia may not be a "magic bullet" (in terms of significantly increasing grades) there seems to be a consensus among students that multimedia learning is preferable instead of conventional learning methods. This new media open and distance learning, and information and communication technologies are much more than techniques and tools (Cornu, 2007). Therefore this conclusion indicates that computerbased learning systems deserve more research on how to improve the interactivity in multimedia environments, as well as on how to evaluate them.

\section{References}

Apperson, J.M., Laws, E.L., Scepansky, J.A. (2006). The impact of presentation graphics on students' experience in the classroom. Computers \& Education, 47(1), 116-126.

Cipriano, J.J., Jahn, W.T., White, M.E. (1997). Photographic Manual of Regional Orthopedic and Neurological Tests. Lippincott Williams \& Wilkins, Philadelphia.

Clarkson, H.M. (2000). Musculoskeletal Assessment, Joint Range of Motion and Manual Muscle Strength. Lippincott Williams \& Wilkins, Philadelphia.

Cornu, B. (2007). New media and open and distance learning: New challenges for education in a knowledge society. Informatics in Education, 6(1), 43-52.

Cutter, N.C., Kevorkian, C.G. (1999). Handbook of Manual Muscle Testing. McGraw Hill, New York.

Evans, C., Gibbons, N.J. (2007). The interactivity effect in multimedia learning. Computers \& Education, 49(4), 1147-1160.

Evans, C., Sabry, K. (2002). Evaluation of the interactivity of web-based learning systems: Principles and process. Innovations in Education and Teaching International, 40, 89-99.

Fieschi, M. (2002). Information technology is changing the way society sees health care delivery. International Journal of Medical Informatics, 66(3), 85-93.

Hislop, H.J., Montgomery, J. (2007). Daniels \& Worthingham's Muscle Testing: Techniques of Manual Examination. Saunders, Philadelphia.

Hwang, W.Y., Chen, N.S., Hsu, R.L. (2006). Development and evaluation of multimedia whiteboard system for improving mathematical problem solving. Computers \& Education, 46(2), 105-121.

Jan, S.V.S., Hilal, I., Salvia, P., Sholuka, V., Poulet, P., Kirokoya, I., Marcel, R. (2003). Data representation for joint kinematics simulation of the lower limb within an educational context. Medical Engineering and Physics, 25(3), 213-220.

Jonassen, D. (1992). Objectivism versus constructivism: Do we need a new philosophical paradigm? Education Technology Research and Development, 39, 5-14.

Kendall, F.P., McCreary, E.K., Provance, P.G., Rodgers, M.M., Romani, W.A. (2005). Muscles: Testing and Function with Posture and Pain. Lippincott Williams \& Wilkins, Philadelphia.

Larman, C. (2004). Applying UML and Patterns: An Introduction to Object-Oriented Analysis and Design and Iterative Development. Prentice Hall, New Jersey.

Laurillard, D. (2002). Rethinking University Teaching. Routledge, London.

Lentz, R., Dowd, S. (2003). Macromedia Flash MX 2004 Bible. Visual.

McGown, H., Faust, G.W. (1971). Computer-assisted instruction in physiotherapy: A pilot program, Physiotherapy, 51(10), 1113-1120.

Mayer, R.E. (2001). Multimedia Learning. Cambridge University Press, Cambridge.

Saarinen-Rahiika, H., Binkley, J.M. (1998). Problem-based in physiotherapy: A review of the literature and over view of the McMaster university experience, Physiotherapy, 78(2), 195-209.

Schär, S., Krueger, H. (2000). Using new learning technologies with multimedia. IEEE Multimedia, 7(3), 4051. 
Schrum, L., Berge, Z. (1997). Creating student interaction within the educational experience: A challenge for online educators. Canadian Journal of Educational Communication, 26(3), 133-144.

Shortliffe, E.H., Perreault, L.E., Wiederhold, G., Fagan, L.M. (2001). Medical Informatics: Computer Applications in Health Care and Biomedicine. Springer-Verlag, New York.

Smith, L.K., Weiss, E.L., Lehmkuhl, L.D. (1996). Brunnstrom's Clinical Kinesiology. F.A. Davis, Philadelphia.

Washington, N., Parnianpour, M. (1997). Using CAI to accommodate a variety of learning styles in a biomechanics course. Biomedical Science Instruments, 33, 41-46.

Wilkinson, S.G. (2007). Computerized Ontology Methods for Teaching Musculoskeletal Topics to Physical Therapy Students, PhD Thesis, The University of Utah.

L.V. Castilho-Weinert graduated in Physical Therapy by the Catholic Pontifical University of Parana (PUC-PR) in 2002 and obtained the MSc degree in computer science from the Federal University of Technology of Parana (UTFPR) in 2005. To date she is a PhD student in computer science at UTFPR. Her current research interests are informatics in health education and decision support systems in healthcare.

H.S. Lopes obtained the BSc and MSc degrees in electrical engineering and computer science from the Federal University of Technology of Parana (UTFPR), Brazil respectively in 1979 and 1990, and a PhD degree from the Federal University from Santa Catarina, in 1996. Currently, he is an associate professor in the Department of Electronics and head of the Laboratory of Bioinformatics and Medical Informatics of UTFPR. Dr. Lopes has served as member of program committee of many international conferences and editorial board of distinguished journals. To date, Dr. Lopes has supervised $30 \mathrm{MSc}$ dissertations and $\mathrm{PhD}$ theses, and published more than 150 papers in conferences and scientific journals. His current research interests are medical and health informatics, informatics in education and bioinformatics.

\title{
Kompiuteriai fizinès psichoterapijos ugdyme: interaktyvus multimedinis mokymasis naudojant „MuStreT“ programa
}

\author{
Luciana Vieira CASTILHO-WEINERT, Heitor Silvério LOPES
}

Raumenu jègos tyrimai yra ypač svarbūs fizioterapinèms diagnozèms ir yra sudètinga mokymo problema. Fizinès psichoterapijos srityje sukurta dar labai nedaug mokomosios ar diagnostinès programinès įrangos. Šiame straipsnyje aprašoma „MuStreT.plètra ir vertinimas, o taip pat mokomoji multimedinè kompiuterinė priemoné, skirta fizinès psichoterapijos studentams. „MuStreT“ programos kūrèjai rèmėsi konstruktyvizmo koncepcija: programoje naudojamas hipertekstas, filmu iškarpos, pasakojimai, animacija, klausimynai. Programinè ịranga buvo sukurta naudojant „Unified Modeling“ kalbos sąvokas ir realizuota naudojant animacijos kūrimo priemones. „MuStreT“ programą vertino fizinès psichoterapijos studentai (kiekybinis tyrimas) ir fizinès psichoterapijos specialistai bei dėstytojai, taip pat informatikos mokslo studentai (kokybinis tyrimas). Rezultatai parodè, kad naudojant „MuStreT“ mokymasis pagerẻjo dèl jos sąveikos galimumo ir ịvairialypès terpès funkciju. Straipsnyje parodoma, kad informatikos panaudojimas fizinès psichoterapijos ugdyme daro didelę įtaką mokymo ir mokymosi gerinimui. 